\title{
EFFECT OF PLOUGHING DEPTH AND MANURE ON CORN YIELD
}

\author{
(Received:15.11.2007)
}

\author{
By \\ M. A. El-Nady
}

Soil Science Department, Faculty of Agriculture, Cairo University, Egypt.

\begin{abstract}
A field experiment was conducted to evaluate the effect of three tillage and three manure treatments on some soil physical properties, grain yield and some yield components of corn. The tillage treatments were no tillage (To), chisel plough to $10 \mathrm{~cm}\left(\mathrm{~T}_{1}\right)$, and to $20 \mathrm{~cm}\left(\mathrm{~T}_{2}\right)$ soil depth. The manure treatments were, cattle manure $\left(M_{1}\right)$, rice straw $\left(M_{2}\right)$, and ( $1 / 2$ cattle manure $+1 / 2$ rice straw) $\left(M_{3}\right)$. Measurements of soil bulk density $(\mathrm{Bd})$ and soil penetration resistance (PR) were taken to quantify the ploughing depth. Available water capacity (AWC) was calculated for all treatments. The measurements were taken twice, after ploughing and before harvest. Yield and yield components (weight of 100 grain yield (gm), weight of ear (gm), and grain yield/fed.) were obtained. The data showed that the lowest (Bd) and (PR) were obtained in the surface layer of $T_{2}$ and $M_{2}$ treatments while, the highest (AWC) was recorded in $T_{0}$ and $M_{2}$ treatments. The results also showed that the highest 100 grain weight, ear weight and grain yield were obtained with $\mathrm{T}_{2}$ as compared with $\mathrm{T}_{1}$ and To. However, the difference among the ploughing treatments was not significant. Application of manure showed that the highest 100 grain weight, ear weight and grain yield of corn were recorded with $\left(\mathrm{M}_{2}\right)$ comparing with (M1) and (M3) treatments. Interaction effect between ploughing depth and manure treatments influenced the grain yield, and the yield components. The combination treatment $\left(\mathrm{T}_{2} \mathrm{M}_{2}\right)$ recorded the highest 100 grain weight, ear weight and grain yield. A significant difference between $\left(T_{2} M_{2}\right)$ and $\left(T_{2} M_{3}\right)$ was obtained. These results concluded that the combination of soil ploughing to $20 \mathrm{~cm}$ depth with the application of rice straw increased corn grain yield. This increase is due to the effect of tillage and the incorporation of rice straw on the improvement of the soil physical properties.
\end{abstract}

Key words: corn, manure, ploughing depth, rice straw, soil bulk density, soil penetration resistance, water capacity, yield components.

\section{INTRODUCTION}

Soil tillage and manuring have been reported to have a great influence on crop production. Soil tillage and manure application can change the physical conditions and can affect nutrition status of the soil. Different tillage systems can be used to maintain the optimum crop yield. Manure can be used to improve soil properties and overcome nutrient deficiencies which reduce requirements for chemical fertilizer. Therefore, choosing the most adequate tillage and manuring practice is necessary for sustaining the optimum soil physical properties and reducing chemical fertilizer addition.

Chen (1993) explained that, tillage modifies soil structure. Conventional ploughing usually yields a looser soil structure in the tilled layer than no-tillage which leaves the soil relatively intact. Motavalli et al. (2003) indicated that subsoil compaction may reduce the availability and uptake of water and plant nutrients, thereby lowering crop yields. Deep tillage breaks the hard layers to help the roots to extend in the deeper layers. It facilitates easy uptake of water as well as nutrients by the roots, Bongki et al. (1996).
Singh and Singh (1996) reported that different tillage operations may influence the physical properties such as, soil porosity, air-filled porosity, and hydraulic conductivity. Buschiazzo et al., (1998) indicated that soil physical properties changes affected by different soil tillage treatments could influence yield level of grown crops. Soil physical properties are connected directly and indirectly with growth of the root system of crops (Logsdon et al., 1987, Sidiras and Kahnt, 1988, Azooz et al., 1995 and Varsa et al., 1997). On the other hand, manure is a useful soil amendment that can serve as a low cost source of organic fertilizer for crop production and as a soil conditioner that may improve the physical and chemical conditions of the soil, Campbell et al. (1986).

Addition of the organic matter from different origins to the soil is an important practice in improving some soil physical properties, consequently increasing soil productivity, Ekwue (1990). Organic amendment increases the total porosity, moisture content, and organic matter content in the soil which improve its structure (Mbagwu, 1989). Borresen (1999) found that straw 
residues, on the soil surface increased maize grain yields.

The objective of this study was to evaluate the effect of different tillage depths and different manure application on some soil physical properties, yield component and grain yield of corn.

\section{MATERIALS AND METHODS}

The experiment was conducted at the Agricultural Experiment and Research Station, Faculty of Agriculture, Cairo University. The experiment area was $16 \mathrm{~m}$ width and $50 \mathrm{~m}$ length and was laid out in split plot design with three replications. Soil samples were collected to soil depths. The available water capacity was calculated as the difference between the moisture content at field capacity and the wilting point that determined at -0.33 and -15 bars according to Klute (1986) for the soil depths of $0-10$ and $10-20 \mathrm{~cm}$. The plants were harvested at maturity, four months after planting. The studied yield parameters were weight of 100-grain (gm), weight of ear (gm), and grain yield.

\section{RESULTS AND DISCUSSION}

Some physical and chemical characteristics of the studied soil are presented in Table (1). The soil is loamy texture in the surface layer $(0-20 \mathrm{~cm})$ and clay loam in the sub surface layer $(20-40 \mathrm{~cm})$.

Table (1): Some physical and chemical characteristics of the experimental soil.

\begin{tabular}{|c|c|c|c|c|c|c|c|c|}
\hline \multirow{2}{*}{ Soil depth (cm) } & \multicolumn{4}{|c|}{ Particle size fraction (\%) } & \multirow{2}{*}{$\begin{array}{c}\text { Texture } \\
\text { class }\end{array}$} & \multirow{2}{*}{ Soil pH } & \multirow{2}{*}{ Ec dS/m } & \multirow{2}{*}{ O.M \% } \\
\cline { 2 - 9 } & c.sand & f.sand & Silt & clay & & & \\
\hline $0-20$ & 4.96 & 37.81 & 33.52 & 23.71 & Loam & 7.62 & 1.83 & 2.77 \\
\cline { 2 - 10 } $20-40$ & 3.52 & 34.17 & 36.07 & 26.24 & C.loam & 7.84 & 2.28 & 2.52 \\
\hline
\end{tabular}

determine some soil properties before treatment application (Table, 1). The experiment was divided into three parts. The first part was the plough treatments without manure application. It consisted of three tillage treatments, no tillage (To) chisel plough to $10 \mathrm{~cm}$ depth $\left(\mathrm{T}_{1}\right)$ and chisel plough to $20 \mathrm{~cm}$ depth $\left(\mathrm{T}_{2}\right)$. The second part was the manure treatments which included three manure treatments; cattle manure 2.10 ton/Fed. $\left(\mathrm{M}_{1}\right)$, rice straw 2.10 ton/Fed. $\left(\mathrm{M}_{2}\right)$, and cattle manure 1.10 ton/Fed. + rice straw 1.10 ton/Fed. $\left(\mathrm{M}_{3}\right)$. Rice straw was chopped into short pieces and incorporated with the soil surface layer manually. The third part was the combination between the ploughing depths and the manure treatments. After preparing the treatments, corn seeds (Zea mays L.) were sown. Two corn seed $\mathrm{s}$ were planted per hill, $30 \mathrm{~cm}$ apart from each other and at a distance of $70 \mathrm{~cm}$ between each row. Half the recommended dose of NPK according to the Ministry of Agriculture (2005) was added. The plants were thinned to one plant per hill before the first irrigation. Plots were hand hoed twice to control weeds after 21 and 45 days of planting. The first irrigation was applied 21 days after planting and the following irrigation was applied at 14 day intervals. Soil samples from each treatment in the three replications were collected a day after the treatments were applied and two weeks before harvest. Bulk density was determined from oven dried undisturbed cores of $5 \mathrm{~cm}$ diameter and $5 \mathrm{~cm}$ height according to Klute (1986). Soil penetration resistance was measured using the penetrologger with cone type $1 \mathrm{~cm}^{2}$ and an angle of $60^{\circ}$. The bulk density and the soil penetration resistance were measured for the $0-10 \mathrm{~cm}, 10-20 \mathrm{~cm}$, and $20-30 \mathrm{~cm}$

\subsection{Soil physical properties \\ 3.1.1. Bulk density (Bd)}

Soil bulk density of the different plough and manure treatments (after ploughing and before harvest) are presented in Table (2). The data indicate that $(\mathrm{Bd})$ decreased with ploughing. The lowest $(\mathrm{Bd})$ values were obtained with $\mathrm{T}_{2}$ followed by $T_{1}$ comparing with $T_{0}$. Surface $(B d)$ was quite low compared to those of subsurface of $T_{1}, T_{2}$ and $\mathrm{T}_{0}$. The highest $(\mathrm{Bd})$ of $\left(1.41\right.$ and $\left.1.44 \mathrm{Mg} \cdot \mathrm{m}^{-3}\right)$ was obtained with $\mathrm{T}_{0}$ at $20-30 \mathrm{~cm}$ soil depth after ploughing and before harvest, respectively. The differences among ploughing treatments were significant at $0-10$ and $10-20 \mathrm{~cm}$ depth for bulk density values obtained after ploughing only. Bulk density of the soil was also influenced by manure treatments. (Bd) increased with $\mathrm{M} 1$ and $\mathrm{M} 3$, while decreased with $\mathrm{M}_{2}$ treatment at 0-10 $\mathrm{cm}$ depth after ploughing and before harvest. Kuchenbuch and Ingram (2004) reported that bulk densities were lowered with the incorporation of organic materials. However, the differences among manure treatments were not significant. Concerning the interaction effect of ploughing and manuring on (Bd), the data in Table (2) show that the highest bulk density was obtained with $\mathrm{T}_{0} \quad \mathrm{M}_{3}$ whereas, the lowest bulk density was recorded in the treatment combination of $\mathrm{T}_{2} \mathrm{M}_{2}$.

\subsubsection{Penetration resistance $(P R)$}

Data of penetration resistance (Table 3) show that penetration resistance of the soil varied with the ploughing depth. The lowest (PR) measured after ploughing and before harvest was recorded with $\mathrm{T}_{2}$ at $0-10 \mathrm{~cm}$ depth whereas the highest $(\mathrm{PR})$ value 
Table (2): Effect of ploughing and manure treatments and the interaction between them on soil bulk density.

\begin{tabular}{|c|c|c|c|c|c|c|}
\hline \multirow{4}{*}{ Treat. } & \multicolumn{6}{|c|}{ Bulk density (Mg. $\mathrm{m}^{-3}$ ) } \\
\hline & \multicolumn{3}{|c|}{ After ploughing } & \multicolumn{3}{|c|}{ Before harvest } \\
\hline & \multicolumn{6}{|c|}{ Depth of soil (cm) } \\
\hline & 0-10 & $10-20$ & $20-30$ & 0-10 & $10-20$ & $20-30$ \\
\hline \multicolumn{7}{|c|}{ Tillage practice } \\
\hline $\mathrm{T}_{0}$ & 1.25 & 1.36 & 1.41 & 1.29 & 1.33 & $\overline{1.42}$ \\
\hline $\mathrm{T}_{1}$ & 1.09 & 1.22 & 1.39 & 1.30 & 1.37 & 1.44 \\
\hline $\mathrm{T}_{2}$ & 1.07 & 1.12 & 1.36 & 1.19 & 1.23 & 1.39 \\
\hline L.S.D $5 \%$ & 0.11 & 0.06 & $\mathrm{~ns}$ & ns & $\mathrm{ns}$ & $\mathrm{ns}$ \\
\hline $1 \%$ & 0.19 & 0.12 & & & & \\
\hline \multicolumn{7}{|c|}{ Manure treatments } \\
\hline $\mathrm{M}_{1}$ & 1.25 & 1.35 & 1.49 & 1.32 & 1.37 & 1.51 \\
\hline $\mathrm{M}_{2}$ & 1.21 & 1.31 & 1.45 & 1.26 & 1.34 & 1.46 \\
\hline $\mathrm{M}_{3}$ & 1.26 & 1.34 & 1.44 & 1.31 & 1.38 & 1.48 \\
\hline L.S.D $5 \%$ & $\mathrm{~ns}$ & $\mathrm{~ns}$ & $\mathrm{~ns}$ & $\mathrm{~ns}$ & ns & $\mathrm{ns}$ \\
\hline & \multicolumn{5}{|c|}{ Interaction between treatments } & \\
\hline $\mathrm{T}_{0} \mathrm{M}_{1}$ & 1.25 & 1.32 & 1.39 & 1.26 & 1.29 & 1.45 \\
\hline $\mathrm{T}_{0} \mathrm{M}_{2}$ & 1.18 & 1.30 & 1.35 & 1.23 & 1.24 & 1.42 \\
\hline $\mathrm{T}_{0} \mathrm{M}_{3}$ & 1.24 & 1.37 & 1.40 & 1.31 & 1.30 & 1.43 \\
\hline $\mathrm{T}_{1} \mathrm{M}_{1}$ & 1.06 & 1.24 & 1.37 & 1.25 & 1.33 & 1.42 \\
\hline $\mathrm{T}_{1} \mathrm{M}_{2}$ & 0.96 & 1.17 & 1.34 & 1.16 & 1.29 & 1.39 \\
\hline$T_{1} M_{3}$ & 1.08 & 1.19 & 1.38 & 1.20 & 1.34 & 1.44 \\
\hline $\mathrm{T}_{2} \mathrm{M}_{1}$ & 1.01 & 1.03 & 1.37 & 1.22 & 1.29 & 1.41 \\
\hline $\mathrm{T}_{2} \mathrm{M}_{2}$ & 0.95 & 1.12 & 1.35 & 1.18 & 1.26 & 1.38 \\
\hline $\mathrm{T}_{2} \mathrm{M}_{3}$ & 0.98 & 1.15 & 1.36 & 1.21 & 1.31 & 1.41 \\
\hline L.S.D & & & & & & \\
\hline $5 \%$ & 0.09 & 0.12 & 0.06 & 0.05 & 0.06 & 0.07 \\
\hline
\end{tabular}

Table (3): Effect of ploughing and manure treatments and the interaction between them on soil penetration resistance.

\begin{tabular}{|c|c|c|c|c|c|c|}
\hline \multirow{4}{*}{ Treat. } & \multicolumn{6}{|c|}{ Penetration resistance (MPa) } \\
\hline & \multicolumn{3}{|c|}{ After ploughing } & \multicolumn{3}{|c|}{ Before harvest } \\
\hline & \multicolumn{6}{|c|}{ Depth of soil (cm) } \\
\hline & 0-10 & $10-20$ & $20-30$ & 0-10 & $10-20$ & $20-30$ \\
\hline \multicolumn{7}{|c|}{ Tillage practice } \\
\hline $\mathrm{T}_{0}$ & 1.53 & 1.86 & 1.97 & 1.61 & 2.27 & 2.46 \\
\hline $\mathrm{T}_{1}$ & 1.47 & 1.71 & 1.93 & 1.59 & 1.98 & 2.41 \\
\hline $\mathrm{T}_{2}$ & $1 . .32$ & 1.45 & 1.83 & 1.52 & 1.79 & 2.27 \\
\hline L.S.D $5 \%$ & $\mathrm{~ns}$ & 0.14 & ns & ns & 0.29 & ns \\
\hline $1 \%$ & & 0.26 & & & 0.53 & \\
\hline \multicolumn{7}{|c|}{ Manure treatments } \\
\hline $\mathrm{M}_{1}$ & 1.47 & 1.82 & 2.1 & 1.55 & 1.78 & 2.24 \\
\hline $\mathrm{M}_{2}$ & 1.26 & 1.53 & 1.92 & 1.43 & 1.81 & 2.17 \\
\hline $\mathrm{M}_{3}$ & 1.29 & 1.61 & 1.98 & 1.51 & 1.94 & 2.21 \\
\hline L.S.D $5 \%$ & 0.12 & $\mathrm{~ns}$ & $\mathrm{~ns}$ & ns & ns & $\mathrm{ns}$ \\
\hline $1 \%$ & 0.22 & & & & & \\
\hline & \multicolumn{5}{|c|}{ Interaction between treatments } & \\
\hline $\mathrm{T}_{0} \mathrm{M}_{1}$ & 1.39 & 1.76 & 1.91 & 1.48 & 1.56 & 2.11 \\
\hline $\mathrm{T}_{0} \mathrm{M}_{2}$ & 1.26 & 1.59 & 1.89 & 1.42 & 1.54 & 1.97 \\
\hline $\mathrm{T}_{0} \mathrm{M}_{3}$ & 1.36 & 1.97 & 1.98 & 1.71 & 1.67 & 2.17 \\
\hline$T_{1} M_{1}$ & 1.21 & 1.63 & 2.13 & 1.33 & 1.41 & 1.92 \\
\hline$T_{1} M_{2}$ & 1.12 & 1.43 & 1.70 & 1.29 & 1.37 & 1.89 \\
\hline $\mathrm{T}_{1} \mathrm{M}_{3}$ & 1.23 & 1.51 & 2.18 & 1.36 & 1.49 & 2.21 \\
\hline $\mathrm{T}_{2} \mathrm{M}_{1}$ & 0.86 & 1.25 & 1.96 & 1.29 & 1.41 & 2.13 \\
\hline $\mathrm{T}_{2} \mathrm{M}_{2}$ & 0.73 & 0.93 & 1.64 & 1.26 & 1.45 & 1.97 \\
\hline $\mathrm{T}_{2} \mathrm{M}_{3}$ & 1.16 & 1.27 & 2.46 & 1.32 & 1.51 & 2.31 \\
\hline L.S.D. & & & & & & \\
\hline $5 \%$ & 0.11 & 0.13 & 0.24 & 0.09 & 0.11 & $\mathrm{~ns}$ \\
\hline $1 \%$ & 0.16 & 0.18 & 0.33 & 0.12 & 0.15 & \\
\hline
\end{tabular}

was recorded under To at $20-30 \mathrm{~cm}$ soil depth. These results reveal the effect of ploughing on reducing soil penetration resistance. A significant difference among the tillage treatment is evident only at the $10-20 \mathrm{~cm}$ depth after ploughing and also before harvest. Manure treatments also affected (PR) values that were measured after ploughing and before harvest. The lowest (PR) was obtained with $M_{2}$ while the highest PR was obtained with $M_{1}$. Interaction effect of ploughing and manuring on (PR) is recorded (Table 3 ). The data show that the combination treatment $\left(\mathrm{T}_{2} \mathrm{M}_{2}\right)$ significantly reduced penetration resistance as compared with the other treatments. The data also show that soil penetration resistance increased with time under all treatments at the three studied depths.

\subsubsection{Available water capacity (AWC)}

The effects of tillage, manuring and the interaction between them on soil available water capacity (AWC) are presented in Table (4). The data calculated after tillage treatment applications show that (AWC) increased in $\mathrm{T}_{0}$ treatment and decreased in $\mathrm{T}_{1}$ and $\mathrm{T}_{2}$ treatments. Kouwenhoven et al.(2002) reported that shallow ploughing was generally associated with high moisture content. However, the only significant difference among ploughing treatments was obtained after tillage at $10-20 \mathrm{~cm}$ depth. The data also show that (AWC) was increased with increasing the depth of soil. Radcliffe et al. (1988) reported that the greater (AWC) at the lower depth may be due to higher proportion of micro pores and more compaction compared with the upper depths. Concerning the effect of manure treatments on (AWC), it is observed that $M_{2}$ retained more water than $M_{1}$ and $\mathbf{M}_{3}$. These results are in agreement with Kuchenbuch and Ingram (2004) as they found that the water holding capacity of the soil was increased by incorporation of organic matter, especially the rice straw. A significant difference among manure treatments was found only before harvest at 0-10 $\mathrm{cm}$ depth. It is also observed that the combination treatment $\left(\mathrm{T}_{0} \mathrm{M}_{2}\right)$ had the highest (AWC) while, the lowest was obtained with $\left(\mathrm{T}_{2} \mathrm{M}_{3}\right)$. Rice straw application raised up the moisture retained in the combination treatments as compared with the ploughing treatments alone.

\subsection{Effect of ploughing and manuring on yield components}

\subsubsection{Effect on 100 - grain weight}

Table (5) represents the weights of 100 grains under plough and manure treatments. The data show that the highest weight of 100 grains among tillage treatments was obtained with $\mathrm{T}_{2}$ followed by $\mathrm{T}_{1}$ comparing with $T_{0}$. However, the differences among $\mathrm{T}_{1}, \mathrm{~T}_{2}$ and $\mathrm{T}_{0}$ were not significant. Data of 
manure treatments show that $\mathrm{M}_{2}$ increased weight of 100 grains by $14 \%$ over $M_{1}$ and by $23 \%$ over $M_{3}$ and the difference was significant between $\mathrm{M}_{2}$ and both $\mathrm{M}_{1}$ and $\mathrm{M}_{3}$. Interaction effect between plough and manure treatments Table (6) shows that the highest weight of 100 grains was obtained with $T_{2}$ $\mathrm{M}_{2}$ which increased the weight of 100 grains by $15.5 \%$ over $\mathrm{T}_{2} \mathrm{M}_{1}$ and by $28 \%$ over $\mathrm{T}_{2} \mathrm{M}_{3}$. The lowest 100 grains weight was obtained with $\mathrm{T}_{1} \mathrm{M}_{3}$.

The results also show that the combination between ploughing and manuring resulted in an increase of 100-grains weight when comparing with plough and manure treatments without interaction. A significant difference was only obtained between $\mathrm{T}_{2} \mathrm{M}_{2}$ and $\mathrm{T}_{2} \mathrm{M}_{3}$.

Table (4): Effect of ploughing and manure treatments and the interaction between them on available water capacity.

\begin{tabular}{|c|c|c|c|c|}
\hline \multirow{4}{*}{ Treat. } & \multicolumn{4}{|c|}{ Available water capacity (AWC \%) } \\
\hline & After & ghing & Befor & arvest \\
\hline & \multicolumn{4}{|c|}{ Depth of soil $(\mathrm{cm})$} \\
\hline & $0-10$ & $10-20$ & $0-10$ & $10-20$ \\
\hline \multicolumn{5}{|c|}{ Tillage practice } \\
\hline $\mathrm{T}_{0}$ & 22.58 & 23.49 & 22.32 & 23.93 \\
\hline $\mathrm{T}_{1}$ & 20.70 & 23.11 & 23.41 & 23.46 \\
\hline $\mathrm{T}_{2}$ & 19.62 & 20.80 & 23.19 & 24.25 \\
\hline L.S.D 5\% & ns & 2.14 & ns & ns \\
\hline $1 \%$ & & 3.25 & & \\
\hline \multicolumn{5}{|c|}{ Manure treatments } \\
\hline $\mathrm{M}_{1}$ & 25.93 & 24.19 & 23.61 & 24.51 \\
\hline $\mathrm{M}_{2}$ & 26.13 & 23.96 & 25.82 & 23.93 \\
\hline $\mathrm{M}_{3}$ & 24.42 & 24.13 & 24.54 & 23.72 \\
\hline L.S.D 5\% & ns & ns & 0.84 & $\mathrm{~ns}$ \\
\hline $1 \%$ & & & 1.27 & \\
\hline \multicolumn{5}{|c|}{ Interaction between treatments } \\
\hline $\mathrm{T}_{0} \mathrm{M}_{1}$ & 25.72 & 23.71 & 22.96 & 23.28 \\
\hline $\mathrm{T}_{0} \mathrm{M}_{2}$ & 26.15 & 24.17 & 24.97 & 23.94 \\
\hline $\mathrm{T}_{0} \mathrm{M}_{3}$ & 24.87 & 23.82 & 23.64 & 22.69 \\
\hline $\mathrm{T}_{1} \mathrm{M}_{1}$ & 24.27 & 24.51 & 23.62 & 22.71 \\
\hline $\mathrm{T}_{1} \mathrm{M}_{2}$ & 24.62 & 23.73 & 26.14 & 24.93 \\
\hline $\mathrm{T}_{1} \mathrm{M}_{3}$ & 24.19 & 22.91 & 23.48 & 24.19 \\
\hline $\mathrm{T}_{2} \mathrm{M}_{1}$ & 23.68 & 23.91 & 23.79 & 24.41 \\
\hline $\mathrm{T}_{2} \mathrm{M}_{2}$ & 24.91 & 24.29 & 25.15 & 25.72 \\
\hline $\mathrm{T}_{2} \mathrm{M}_{3}$ & 23.26 & 23.48 & 24.13 & 24.73 \\
\hline \multicolumn{5}{|l|}{ L.S.D. } \\
\hline $5 \%$ & 1.49 & $\mathrm{~ns}$ & 1.16 & 1.75 \\
\hline $1 \%$ & 2.05 & & 1.59 & 2.39 \\
\hline
\end{tabular}

\subsubsection{Effect on ear weight}

Data presented in Table (5) show the ear weight under different plough and manure treatments. The data illustrate that the highest ear weight was obtained with $T_{2}$ comparing with $T_{1}$ and $\mathrm{T}_{0}$. The ploughing treatment $\left(\mathrm{T}_{2}\right)$ increased ear weight by $8 \%$ and $18 \%$ over $\mathrm{T}_{1}$ and $\mathrm{T}_{0}$ respectively. The data also show that the manure treatment $\left(\mathrm{M}_{2}\right)$ recorded the highest ear weight; while $\mathrm{M}_{3}$ recorded the lowest ear weight. $\mathrm{M}_{2}$ increased ear weights by
$10 \%$ and $9 \%$ over $M_{1}$ and $M_{3}$ respectively. Statistically, the difference among $\mathrm{T}_{1}, \mathrm{~T}_{2}$ and $\mathrm{T}_{2}$ and also among $\mathrm{M}_{1}, \mathrm{M}_{2}$ and $\mathrm{M}_{3}$ was not significant.

Interaction effect between ploughing and manuring Table (6) show that the highest ear weight was recorded with $\mathrm{T}_{2} \mathrm{M}_{2}$ which increased the ear weight by about $16.5 \%, 19 \%, 5 \%$ and $20 \%$ over $\mathrm{T}_{0}$ $\mathrm{M}_{2}, \mathrm{~T}_{1} \mathrm{M}_{2}$, and $\mathrm{T}_{2} \mathrm{M}_{1}$ respectively. A significant difference was obtained between $T_{2} M_{2}$ and $T_{2} M_{3}$ and also between $T_{2} M_{1}$ and $T_{2} M_{3}$ The results also illustrate that the combination treatment $\left(\mathrm{T}_{2} \mathrm{M}_{2}\right)$ reflected an increase in ear weight when comparing with tillage and manure treatment alone.

Table (5): Effect of ploughing and manuring on yield components and grain yield of corn.

\begin{tabular}{|c|c|c|c|}
\hline Treatment & $\begin{array}{c}100 \\
\text { grain } \\
\text { weight } \\
\text { (gm) }\end{array}$ & $\begin{array}{c}\text { Ear } \\
\text { weight } \\
(\mathrm{gm})\end{array}$ & $\begin{array}{c}\text { Grain } \\
\text { yield } \\
\text { (Kg. fed.) }\end{array}$ \\
\hline \multicolumn{4}{|c|}{ Tillage practice } \\
\hline $\mathrm{T}_{0}$ & 38.67 & 201.24 & 3827.85 \\
\hline $\mathrm{T}_{1}$ & 41.58 & 226.47 & 4156.24 \\
\hline $\mathrm{T}_{2}$ & 45.09 & 237.26 & 4542.37 \\
\hline L.S.D $5 \%$ & ns & ns & ns \\
\hline \multicolumn{4}{|c|}{ Manure practice } \\
\hline$\overline{M_{1}}$ & $40.39 \mathrm{a}$ & 204.66 & 4017.16 \\
\hline $\mathrm{M}_{2}$ & $44.08 \mathrm{~b}$ & 224.23 & 4292.23 \\
\hline $\mathrm{M}_{3}$ & $37.52 \mathrm{c}$ & 205.78 & 3687.85 \\
\hline L.S.D $5 \%$ & 2.99 & ns & $\mathrm{ns}$ \\
\hline $1 \%$ & 4.53 & & \\
\hline
\end{tabular}

\subsubsection{Effect on grain yield}

The grain yield is presented in Table (5) for the plough treatments and the manure treatments. The data reveal the effect of $\mathrm{T}_{2}$ on increasing corn yield. $\mathrm{T}_{2}$ increased grain yield by $8 \%$ over $\mathrm{T}_{0}$. Data of manure treatments show that the highest grain yield was recorded with $M_{2}$ followed by $M_{1}$ and $M_{3}$ respectively. $\mathrm{M}_{2}$ increased grain yield by $5 \%$ and $19 \%$ over $M_{1}$ and $M_{3}$ respectively. Soil ploughing to $20 \mathrm{~cm}$ depth and incorporation of rice straw may enhance the root environment which resulted in a better growth and yield. However, the differences among the ploughing treatments and among the manure treatments were not significant. The interaction effect between ploughing and manuring treatments, Table (6), illustrates that $\mathrm{T}_{2} \quad \mathrm{M}_{2}$ recorded the highest grain yield among groups and increased yield by $28 \%, 29 \%$ over $\mathrm{T}_{1} \mathrm{M}_{2}$ and $\mathrm{T}_{0} \mathrm{M}_{2}$ respectively. Also $\mathrm{T}_{2} \mathrm{M}_{2}$ raised grain yield over $\mathrm{T}_{2} \mathrm{M}_{1}$ and $\mathrm{T}_{2} \mathrm{M}_{3}$ treatments by $28.4 \%$ and $43 \%$ respectively. A significant difference was only obtained between $T_{2} M_{2}$ and $T_{2} M_{3}$. The data also indicate that the combination effect between ploughing and manuring raised the grain yield by about $16 \%$ and $25 \%$ over $\mathrm{T}_{2}$ and $\mathrm{M}_{2}$, respectively. 
Table (6): Interaction effect of ploughing and manuring on yield components and grain yield of corn.

\begin{tabular}{|l|c|c|c|}
\hline \multirow{2}{*}{ Treatment } & \multicolumn{3}{|c|}{ Weight of } \\
\cline { 2 - 4 } & $\begin{array}{c}\mathbf{1 0 0 -} \\
\text { grains } \\
\text { (gm) }\end{array}$ & Ear (gm) & $\begin{array}{c}\text { Grain } \\
\text { yield } \\
\text { (Kg. fed.) }\end{array}$ \\
\hline $\mathrm{T}_{0} \mathrm{M}_{1}$ & 39.21 & 201.79 & 3791.43 \\
\hline $\mathrm{T}_{0} \mathrm{M}_{2}$ & 43.08 & 215.87 & 4094.77 \\
\hline $\mathrm{T}_{0} \mathrm{M}_{3}$ & 38.65 & 203.18 & 3183.46 \\
\hline $\mathrm{L} . S . D^{2} 5 \%$ & $\mathrm{~ns}$ & $\mathrm{~ns}$ & $\mathrm{~ns}$ \\
\hline \hline $\mathrm{T}_{1} \mathrm{M}_{1}$ & 38.17 & 205.92 & 3897.91 \\
\hline $\mathrm{T}_{1} \mathrm{M}_{2}$ & 40.36 & 211.15 & 4140.17 \\
\hline $\mathrm{T}_{1} \mathrm{M}_{3}$ & 34.52 & 194.99 & 3279.33 \\
\hline $\mathrm{L} . \mathrm{S} . \mathrm{D} 5 \%$ & $\mathrm{~ns}$ & $\mathrm{~ns}$ & $\mathrm{~ns}$ \\
\hline \hline $\mathrm{T}_{2} \mathrm{M}_{1}$ & $41.16 \mathrm{a}$ & $239.25 \mathrm{a}$ & 4105.81 \\
\hline $\mathrm{T}_{2} \mathrm{M}_{2}$ & $47.55 \mathrm{~b}$ & $251.53 \mathrm{~b}$ & 5312.37 \\
\hline $\mathrm{T}_{2} \mathrm{M}_{3}$ & $37.15 \mathrm{c}$ & $209.87 \mathrm{c}$ & 3481.17 \\
\hline $\mathrm{L} . \mathrm{S} . \mathrm{D} 5 \%$ & 7.98 & 21.75 & 1414.83 \\
\hline \hline & 12.09 & 32.96 & 2143.68 \\
\hline $\mathrm{a}-\mathrm{b}$ & 6.39 & 12.28 & 1206.56 \\
\hline $\mathrm{a}-\mathrm{c}$ & 4.01 & $29.38^{*}$ & 624.64 \\
\hline $\mathrm{b}-\mathrm{c}$ & $10.4 *$ & $41.66^{* *}$ & $1831.20^{*}$ \\
\hline
\end{tabular}

In conclusion the response of corn varied with ploughing depth as well as the type of the applied manure. Soil ploughing to $20 \mathrm{~cm}$ depth provided a better environment for roots and that was reflected on increasing the corn grain yield. Application of rice straw associated with soil ploughing reduced bulk density and penetration resistance and increased available water capacity of the soil which resulted in increasing yield components and grain yield. The combination of ploughing to $20 \mathrm{~cm}$ depth with the application of rice straw would provide greater benefits than the ploughing or straw application alone. Application of this practice can be considered as a good management option for corn growers.

\section{REFERENCES}

Azooz R. H., Lowery B. and Daniel T.C.(1995). Tillage and residue management influence on corn growth. Soil and Tillage Res., 33:215227.

Bongki Y., Wooyub A., Yungsin K. and Bongkoo H.(1996).Rates of nitrogen fertilizer application and no tillage methods for flooded reclaimed paddy field RDAJ. Agri. Sci., 38:364-369.

Borresen T.(1999). The effect of straw management and reduced tillage on soil properties and crop yields of spring-sown cereals on two loam soils in Norway. Soil and Tillage Res.51 (1-2): 91-102.

Buschiazzo D.E.,Panigatti J.l. and Unger P.W. (1998). Tillage effects on soil properties and crop production in the subhumid and semiarid
Argentinean Pampas. Soil and Tillage Res., 49: 105-116.

Campbell C.A., Schnitzer M., Stewart J.W.B., J.W.B.,Biederbeck V.O.and Selles F. (1986). Effect of manure and $\mathrm{P}$ fertilizer on properties of a black chernozem in southern Saskatchewan. Can.J.Soil Sci. 66:601-613.

Chen Y. (1993). Soil Thermal Regime Resulting From Reduced Tillage Systems. Ph.D. Thesis. Montreal, Canada: Agricultural Engineering Dept., McGill Univ.

Ekwue E.I. (1990). Organic matter effects on soil strength properties. Soil and Tillage Res., 16:289-297.

Klute A.(1986). Water Retention: Laboratory Methods p.635-662. Methods of Soil Analysis, Part $1,2^{\text {nd }}$ ed.ASA and SSSA, Madison.WI, USA.

Kouwenhoven J.K.,Perdok U.D., Boer J. and Oomen G.J.M.(2002). Soil management by shallow mouldboard ploughing in the Netherlands. Soil and Tillage Res., 65:125139

Kuchenbuch R.O.and Ingram K.T.( 2004). Effects of soil bulk density on seminal and lateral roots of young maize plants (Zea mays L.). J.Plant Nutrition and Soil Sci., vol. 167:229235.

Logsdon S. D., Reneau R. B. Jr. and Parker J.C. (1987). Corn seedling root growth as influenced by soil physical properties. Agron. J., 79:221-224.

Mbagwu J. Sc. (1989). Effects of organic amendments on some physical properties of a tropical. Biological Wastes, 28:1-13.

Ministry of Agriculture (2005). Cultivation of maize in the old lands. The Central Administration for Agricultural Extension. Bulletin No. 961.

Motavalli P.P.,Stevens W.E. and Hartwig G.(2003). Remediation of subsoil compaction effects on corn $\mathrm{N}$ availability by deep tillage and application of poultry manure in a sandytexture soil. Soil and Tillage Res., 71:121-131.

Radcliffe D.E. , Tollner E.W.,HargroveW.L., Clark R.L. and Golabi M.H. (1988). Effect of tillage practices on infiltration and soil strength of a Typic Hapludult soil after ten years. Soil Sci.Soc.Am.J. 52:798-804.

Sidiras N. and Kahnt G. (1988). Biopores, Rooting of Maize and Physical Soil Properties as Influenced by Tillage Systems. $11^{\text {th }}$ ISTRO Conf., Edinburgh : 115-121.

Singh P. K. and Singh Y.(1996). Effect of reduced tillage on soil properties, root growth and grain yield in rice-wheat-system. Indian J. Agric. Res., 30:179-185. 
Varsa E.C., Chong S. K., Abolaji J.O. Farquhar D.

A. and Olsen F. J. (1997). Effect of deep tillage on soil physical characteristics and corn
(Zea mays L.) root growth and production. Soil and Tillage Res., 43:219-228.

\title{
تأثير عمث الحرث والإضافات العضوية للتربة على محصول الذرة

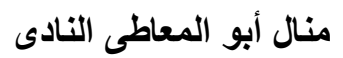 \\ قسم الأراضىـ كليه الزر اعة- جامعة القاهرة -مصر. \\ ملخص م الاقص
}

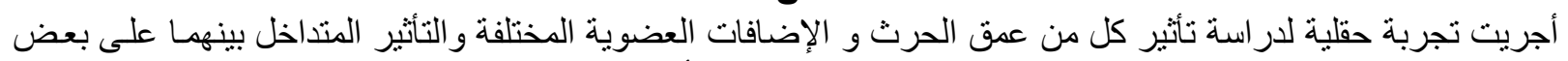

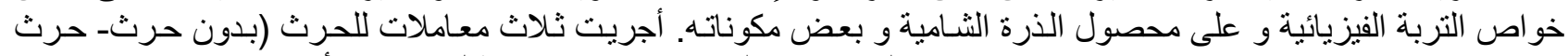

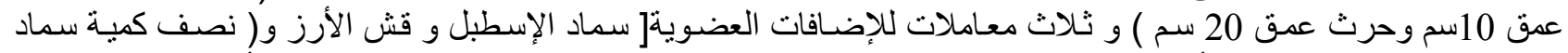
الإسطبل

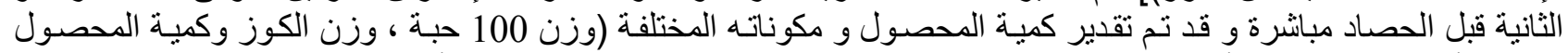

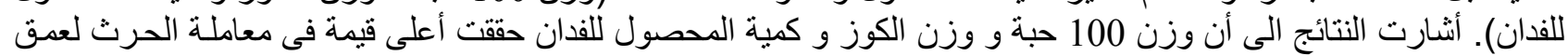

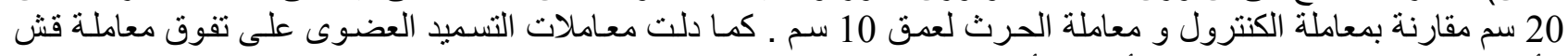

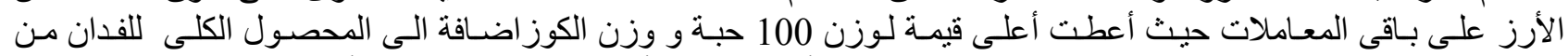

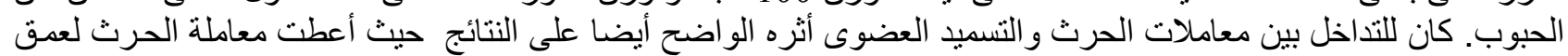

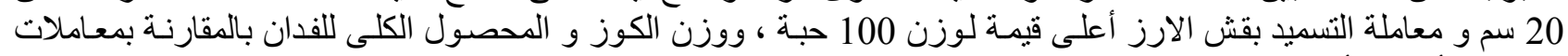

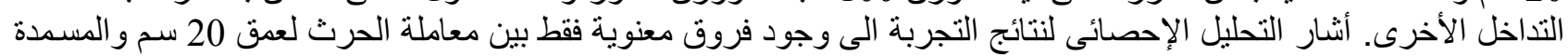

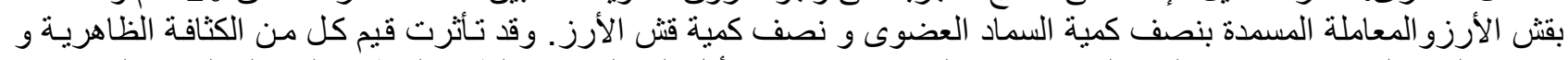

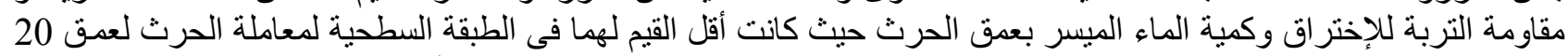

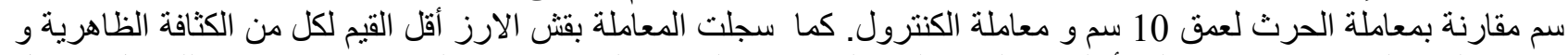

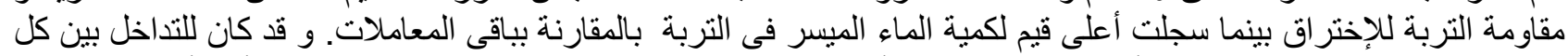

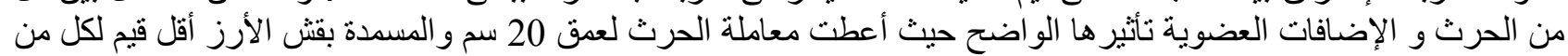

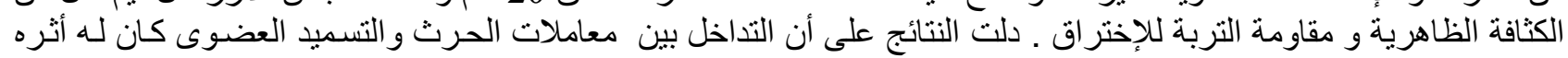

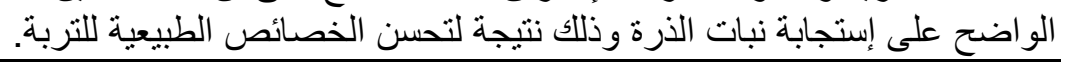

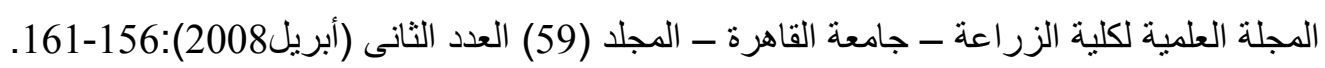

